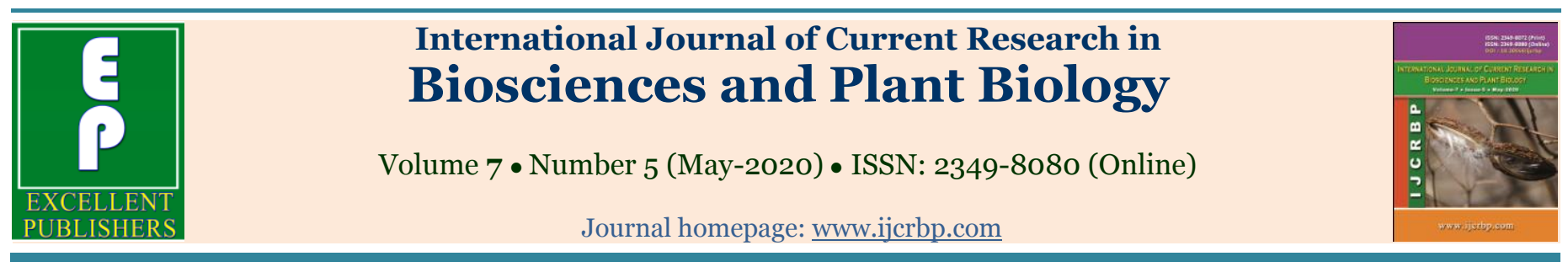

\title{
Contamination of some non-alcoholic drinks by patulin sold in the streets of Daloa (Côte d'Ivoire): case of Bissap (Hibiscus sabdariffa), Gnamankoudji (Zingiber officinale rhizomes) and Tomi (Tamarindus indica)
}

\author{
Ano Guy Serge EHOUMAN', Kra Athanase KOUASSI ${ }^{*}$, Konan Jean-Marie \\ KOUAKOU2, Grah Avit Maxwell BEUGRE1, Karim Sory TRAORE3
}

\begin{abstract}
${ }^{1}$ Laboratoire d'Agrovalorisation, Université Jean Lorougnon GUEDE de Daloa, BP 150 Daloa, Côte d'Ivoire ${ }^{2}$ Laboratoire National d'Appui au Développement Agricole (LANADA), Laboratoire Central d'Agrochimie et d'Ecotoxicologie (LCAE) 04 BP 612 Abidjan 04, Côte d'Ivoire

3Laboratoire des Sciences de l'Environnement (LSE), Université Nangui Abrogoua, 02 BP 801 Abidjan, Côte d'Ivoire
\end{abstract}

${ }^{*}$ Corresponding author; e-mail: kraathanase@yahoo.fr

\begin{tabular}{|c|c|}
\hline Article Info & ABSTRACT \\
\hline $\begin{array}{l}\text { Date of Acceptance: } \\
23 \text { April } 2020\end{array}$ & \multirow{8}{*}{$\begin{array}{l}\text { Bissap (Hibiscus sabdariffa), Gnamankoudji, (Zingiber officinale rhizomes) and Tomi } \\
\text { (Tamarindus indica) was identified as the main traditional non-alcoholic drinks } \\
\text { consumed by the people of Daloa. For the study it's a question of having information } \\
\text { relating to the contamination of these traditional drinks by mycotoxins such as the } \\
\text { patulin recognized toxic for the health of the consumers. To do this, } 30 \text { samples of these } \\
\text { soft drinks were taken from vendors on the streets of the town of Daloa. The detection } \\
\text { and quantification of patulin was carried out using a HPLC with UV detector according } \\
\text { to the ISO } 8128 \text { method. The results of the analyzes show that non-alcoholic artisanal } \\
\text { drinks have fairly high levels of contamination with average PAT contamination levels } \\
\text { exceeding } 200 \mu \mathrm{g} / \mathrm{L} \text { for tomi, bissap and } 150 \mu \mathrm{g} / \mathrm{L} \text { for gnamakoudji. These average } \\
\text { concentrations observed are not in conformity with the EC regulation } \mathrm{N}^{\circ} 1881 / 2006 \text { of } \\
19 / 12 / 2006 \text { which fixes the maximum limits of } 50 \mu \mathrm{O} \text { of PAT/kg in fruit juices and } \\
\text { spirit drinks. Thus the consumption of its drinks on the long topic can present a real } \\
\text { risk for the human health. }\end{array}$} \\
\hline $\begin{array}{l}\text { Date of Publication: } \\
\text { o6 May } 2020\end{array}$ & \\
\hline Keywords & \\
\hline Contamination & \\
\hline HPLC & \\
\hline & \\
\hline & \\
\hline Traditional drinks & \\
\hline
\end{tabular}

\section{Introduction}

Soft drinks have been one of the emerging foods of recent decades. They are much appreciated and abundantly consumed by all age groups and practically at all celebrations (marriage, baptism, birthday, etc.) in many countries of the subregion (Andrieu et al., 2006). Like these countries, in Côte d'Ivoire. These non-alcoholic artisanal drinks are appreciated for their qualities of freshness, their energy intake (Kcal), their richness in vitamins (especially vitamin C) and in trace elements (INRA, 2007). In Daloa, they are sold near roads, in markets and areas with high population densities such as schools and bus stations (Kouassi, et al., 2018). Because of their cost accessible to all budgets, these refreshing drinks occupy an important part in 
the eating habits of the population. However, the quality of these raises concerns among consumers. Indeed, the raw materials used for the production of these drinks undergo in most cases, chemical contamination. Thus, these nonalcoholic drinks considered as an energy source transform over the years into a vector of toxic. Among these panoply of chemical contaminants, there are mycotoxins which are secondary metabolites produced by fungi (molds), which are found in a wide variety of plant foods.

Controlling the health risks associated with these chemical pollutants is considered to be a major issue for the consumer because of their harmful effects on human health. Toxicological studies have revealed the presence of numerous mycotoxins in food with levels exceeding the toxicological standards in force (Ehouman et al., 2017). Patulin is a toxic metabolite produced by several fungal species, mainly Penicillium expansum, it is today one of the major concerns for producers and consumers of beverages. Indeed, the appearance of toxin is only the consequence of the development of the fungus inside the raw material as has been noted (Brause et al., 1996; Tannons et al., 2015).

Several outbreaks of disease have been attributed to street foods such as artisanal beverages around the world (Mihajlovic et al., 2013). This sad observation worries consumers today because the dietary risks linked to the presence of these chemical pollutants (mycotoxins) are at the heart of health and well-being issues. For these reasons, European standards recommend maximum levels for certain mycotoxins including patulin in raw materials and food, in order to protect the consumer. It should be noted that traditional non-alcoholic drinks (tomi, gnamakoudji and bissap) have not been the subject of any toxicological study. Thus, this work is a first in the field of non-alcoholic drinks in Côte d'Ivoire.

The objective of this study is to ensure the health of these traditional drinks sold on the streets of Daloa for health monitoring in order to protect the health of consumers. Specifically, it will be a question of determining and evaluating the maximum levels of patulin (mycotoxin) in these drinks in accordance with the regulations in force.

\section{Materials and methods}

\section{Analysis matrices}

For the search for patulin (mycotoxin), the various analyzes were carried out using non-alcoholic drinks sold in several districts of the town of Daloa. This is the drink commonly called "bissap" which comes from the flowers of Hibiscus sabdariffa, that called "gnamankoudji" is prepared from extracts of rhizomes of Zingiber officinale, and finally the drink called "tomi" which is produced from a mixture of Tamarindus indica fruit.

\section{Sampling site}

The sampling took place exclusively in the city of Daloa Fig. 1, located at $6^{\circ} 53$ north latitude and $6^{\circ}$ 27 west longitude, in different districts of the city during the months of November - December 2018. At this period of the year we have a dry season or the consumption of these drinks by the populations becomes important because of the very strong heat during this period of the year.

\section{Sampling method}

The sampling plan adopted is that of Directive $2005 / 5 / \mathrm{EC}$ applied to fruit juices and or beverages. These traditional drinks were collected at different sites in the city of Daloa. A total of 30 samples were collected (10 samples per type of drink) with vendors chosen at random from the different districts. The different samples collected were labeled (site, date and time of collection) and placed in sterile bottles of approximately $250 \mathrm{ml}$. These bottles were covered with aluminum foil and hermetically sealed to limit oxidation phenomena. The samples were then kept in a cold room at $4{ }^{\circ} \mathrm{C}$ before being sent to the Central Laboratory for Agrochemistry and Ecotoxicology (LCAE).

\section{Patulin analysis protocol}

The analysis protocol is based on the method of assaying patulin by UV HPLC in traditional juices by KpanKpan et al. (2019). For this protocol, the extraction of patulin was done according to the liquid-liquid extraction method (ELL). In fact, a 5 $\mathrm{mL}$ sample of initially diluted beverage concentrate was extracted with 3 successive $5 \mathrm{~mL}$ portions of ethyl acetate, shaking vigorously for 1 minute using 
an agitator (Vortex). The organic phase was extracted with $2 \mathrm{~mL}$ of aqueous sodium carbonate solution (1.4 g / $100 \mathrm{~mL}$ ) by vigorous stirring. Then, the aqueous phase was separated and immediately extracted with $5 \mathrm{~mL}$ of ethyl acetate by stirring for one minute. The organic phase was dried over $2 \mathrm{~g}$ of anhydrous sodium sulfate and filtered through a Whattman No. 4 paper filter.
Subsequently, 5 drops of acetic acid were added to neutralize the carbonate. The extract was just evaporated in a $40^{\circ} \mathrm{C}$ water bath using a rotary evaporator (Rotavapor). The residue is dissolved in $500 \mu \mathrm{L}$ of the $\mathrm{pH} 4$ buffer solution. The sample is filtered on a PTFE disc filter with a porosity of 0.45 $\mu \mathrm{m}$, then the final solution is collected in a vial and injected into the chromatographic system.

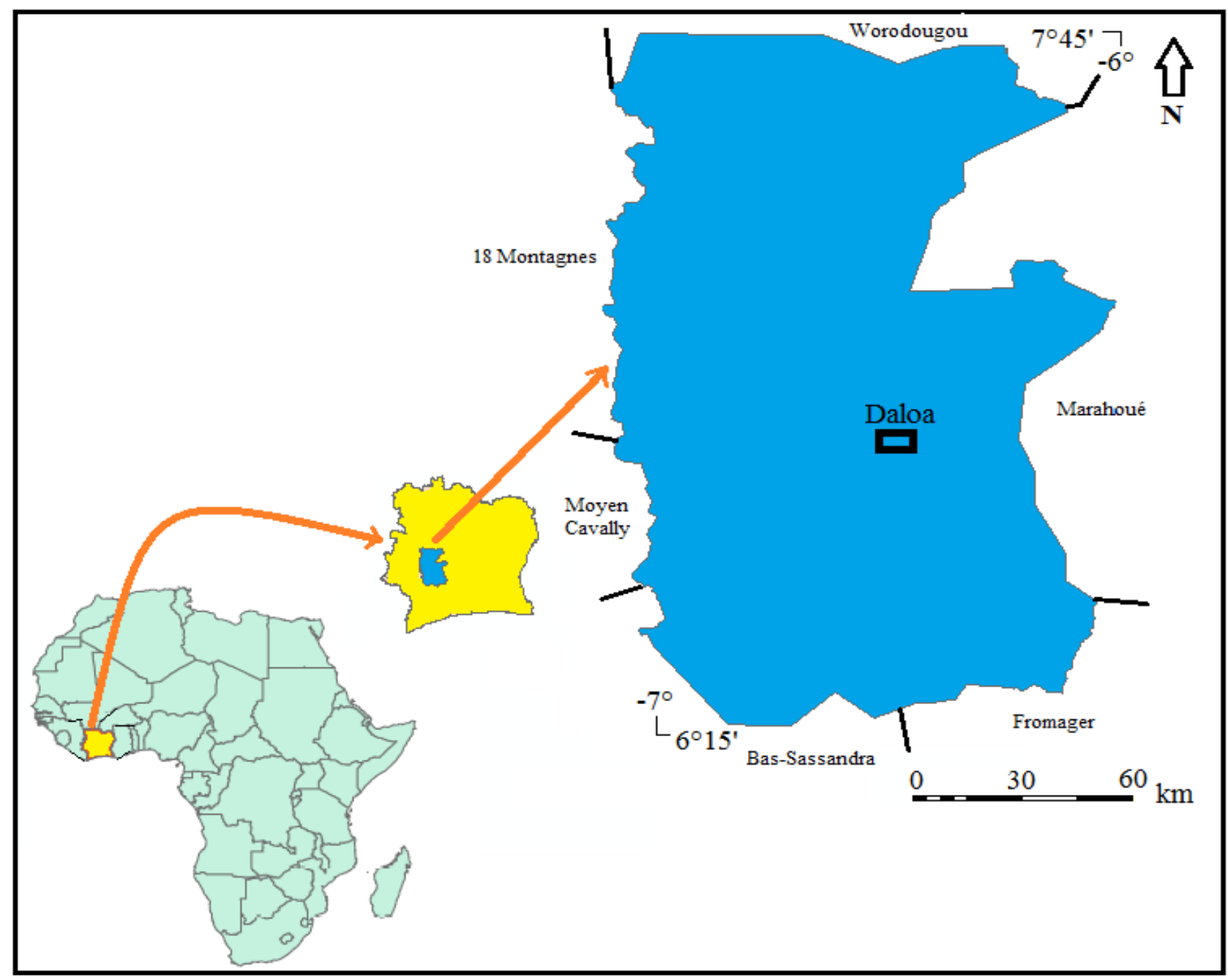

Fig. 1: Location of the study area (Konan, 2018).

\section{Instrumental analysis}

The detection of patulin in fruit juices was carried out using an HPLC system equipped with a LICHROSORB 100 RP-18 column $(5 \mu \mathrm{m}, 250 \mathrm{x} 4$ $\mathrm{mm}$ ID). The elution was carried out in isocratic mode on a mobile phase consisting of acetonitrile / water $(10: 90 ; \mathrm{v} / \mathrm{v}$ ) with a flow rate of $1 \mathrm{ml} / \mathrm{min}$. The oven temperature and the wavelength were set at $40^{\circ} \mathrm{C}$ and $276 \mathrm{~nm}$ respectively. The injection volume was $20 \mu \mathrm{L}$ and the analysis took $10 \mathrm{~min}$.

\section{Results}

\section{Patulin content in traditional juices}

Patulin levels ( $\mu \mathrm{g} / \mathrm{L}$ ) detected in the various traditional juices are listed in the Table 1 below. After analysis, the average contents observed at the level of the various traditional juices vary 
from 157.17 to $283.50 \mu \mathrm{g} / \mathrm{L}$ with rates of $50 \%$ of samples contaminated at the level of gnamankoudji juices and $70 \%$ at the level of bissap and tomi. The following Table 2 gives the average contents in the different drinks by sampling site.

Table 1. Patulin contents detected in the various traditional juices.

\begin{tabular}{llll}
\hline \multirow{2}{*}{ Sampling site } & \multicolumn{2}{l}{ Patulin levels $(\boldsymbol{\mu g} / \mathbf{L})$ of traditional juices } & \\
\cline { 2 - 4 } & GNAMANKOUDJI & BISSAP & TOMI \\
\hline Site 1 & $<$ LQ & 34.03 & 13.06 \\
Site 3 (A) & 683.54 & 285.39 & 64.16 \\
Site 3 (B) & ND & ND & 1175.96 \\
Site 4 & ND & 36.33 & ND \\
Site 5 (A) & $5 \cdot 41$ & 166.38 & 229.86 \\
Site 5 (B) & 51.43 & 37.80 & 582.61 \\
Site 6 & 10.67 & 71.10 & 21.02 \\
Site 7 & 34.79 & ND & ND \\
Site 8 (A) & $<$ LQ & 147.64 & ND \\
Site 8 (B) & ND & ND & 14.94 \\
\hline Average & $\mathbf{1 5 7 . 1 7}$ & $\mathbf{2 0 3 \cdot 3 8}$ & $\mathbf{2 8 3 . 5 0}$ \\
Standard deviation & 263.71 & $\mathbf{2 2 6 . 1 7}$ & 381.57 \\
Maximum content & 683.54 & 716.10 & 1175.96 \\
Minimum content & 5.41 & 34.03 & 13.06 \\
Contaminated sample rate & $\mathbf{5 0 \%}$ & $\mathbf{7 0 \%}$ & $\mathbf{7 0 \%}$ \\
\hline
\end{tabular}

Table 2. Average levels of patulin in the various drinks by sampling site.

\begin{tabular}{llll}
\hline \multirow{2}{*}{ Sampling site } & \multicolumn{4}{l}{ Average levels of patulin $(\boldsymbol{\mu g} / \mathbf{L})$ of various drinks } \\
\cline { 2 - 4 } & TOMI & BISSAP & GNAMANKOUDJI \\
\hline Site 1 & - & $34.03 \pm 6.80$ & $<\mathrm{LQ}$ \\
Site 2 & - & ND & $683.54 \pm 136.70$ \\
Site 3 & $417.73 \pm 83.54$ & $285.39 \pm 57.07$ & ND \\
Site 4 & $406.24 \pm 81.24$ & $36.33 \pm 7.26$ & $5.41 \pm 1.08$ \\
Site 5 & $21.02 \pm 4.20$ & $166.38 \pm 33.27$ & $31.05 \pm 6.21$ \\
Site 6 & ND & $716.10 \pm 143.22$ & $34.79 \pm 6.95$ \\
Site 7 & ND & ND & $<$ LQ \\
Site 8 & $14.94 \pm 2.98$ & $147.64 \pm 29.52$ & ND \\
\hline
\end{tabular}

\section{Statistical analysis}

With regard to the statistical tests carried out, the results reveal that the difference between the levels of contamination (average levels of contamination) of the 3 types of samples of non-alcoholic drinks (Bissap, Gnamankoudji and Tomi is not significant ( $\mathrm{P}>0.05$ ) by a Kruskal-wallis test (Table 3 ).
Table 3. Kruskal-wallis test.

\begin{tabular}{ll}
\hline $\mathrm{H}$ (observed value) & 1.503 \\
$\mathrm{H}$ (critical value) & 5.991 \\
ddl & 2 \\
p-value unilatéral & 0.472 \\
Alpha & 0.05 \\
\hline The H of Kruskal-Wallis is distributed like a $\mathrm{Khi}^{2}$
\end{tabular}




\section{Comparative study between the content of patulin in drinks and the standard (TMA)}

Fig. 2 below shows the Comparison Diagram of Average Patulin Content in Beverages and Standard (TMA). The tomi drink has a high average PAT content greater than five times the authorized content, while the gnamakoudji drink has the lowest PAT content representing approximately three (3) times he authorized content. These average contents do not comply with the regulations which set the maximum limits of $50 \mu \mathrm{g}$ of PAT / $\mathrm{kg}$ in fruit juices and derived drinks according to EC Regulation $\mathrm{N}^{\circ}$ 1881/2006 of 19/12/2006 (Fig. 2).

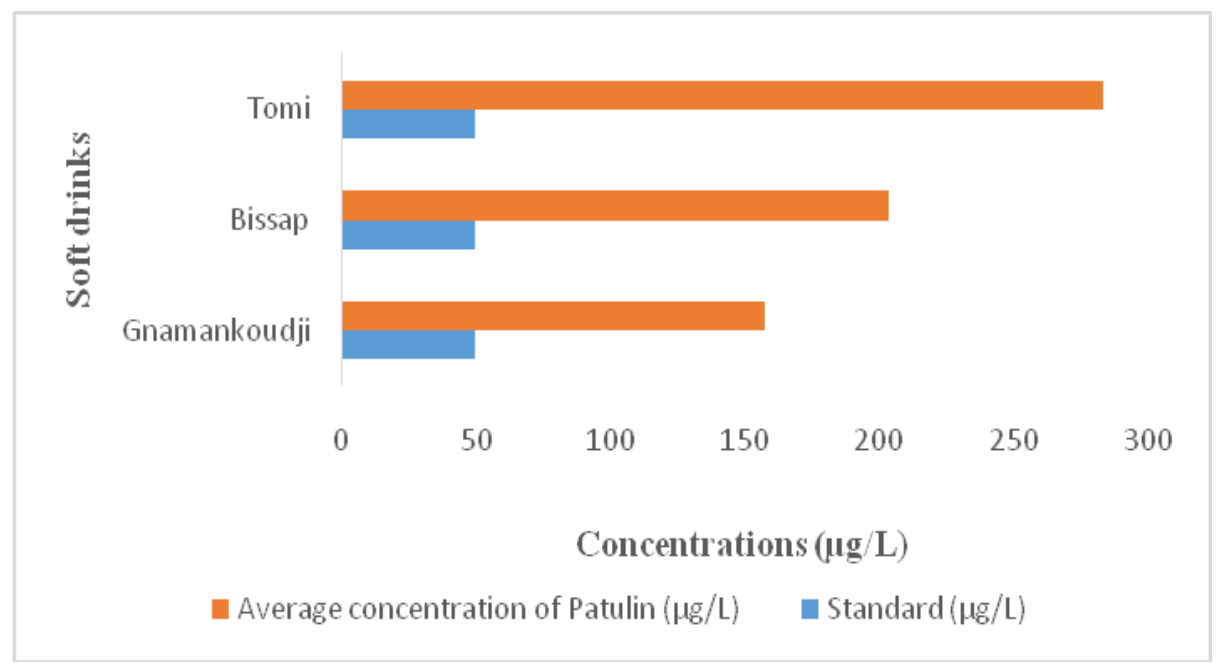

Fig. 2: Comparison of average patulin content in drinks and standard.

\section{Discussion}

The results of the analyses obtained in this study showed a high level of contamination of tomi, gnamakoudji and bissap drinks by PAT. These results are in line with the studies carried out by (Tannons et al., 2015) on apples and derived products, this contamination amounted to more than $60 \%$ of total production. Proving that patulin can be found in all products from the processing of raw materials. However, The level of contamination of tomi drink (70\%), bissap (70\%), and Gnamakoudji (50\%) can be explained on the one hand by the method of conservation of the raw material (leaf, fruit and rhizome) having served for the manufacture of these drinks. This observation was also observed during the work of (Agassounon et al., 2011) and those of (Ndiaye et al., 2015) on the "bissap", which pointed out that molds develop in drinks during storage of raw materials. Also, the only heat treatment at the start of the process could not guarantee the other sources of contamination in the rest of the process.

Conservation being one of the factors which influences the growth of molds and therefore the production of mycotoxins, these raw materials during the conservation phase go through different stages of washing and drying at room temperature, which lasts one or more days. Humidity and temperature are not ideal under these conditions, could promote the growth of fungi as well as the massive production of mycotoxins. On the other hand, the intrinsic composition of the different raw materials and their uncontrolled sales environment highlighted by Ndiaye et al. (2015) explains the low proportion of contamination (50\%) of this drink. It can also be explained by the presence of an external protective envelope in the rhizomes used to make Gnamankoudji. Unlike Gnamankoudji, Hibiscus sabdariffa leaves for bissap and tamarind (Tamarindus indica) fruits for tomi are sold without an external protective covering, which explains the high contamination rates (70\%).

\section{Conclusion}

The present study has enabled us to show that, like apple juice, non-alcoholic artisanal drinks sold on the streets of the town of Daloa have fairly worrying 
contamination levels with average PAT contamination levels exceeding $200 \mu \mathrm{g} / \mathrm{L}$. The samples taken and analyzed gave levels of PAT presenting contamination levels three (3) to five (5) times higher than the European recommendations on the maximum tolerable contents of PAT in fruit juices and derived drinks. The levels of PAT detected in these drinks must challenge us in order to put in place a prevention strategy allowing us to reduce the extent and the consequences of contamination of these drinks by PAT in Ivory Coast. The data obtained will be submitted to the FAO / WHO Coordinating Committee for Africa for a health assessment of the exposure of African populations to mycotoxins.

\section{Conflict of interest statement}

Authors declare that they have no conflict of interest.

\section{Acknowledgement}

We thank all the technicians of the National Laboratory for Agricultural Development Support (LANADA), Central Laboratory of Agrochemistry and Ecotoxicology (LCAE) O4 BP 612 Abidjan 04, Côte d'Ivoire, for their contribution to the realization of the analyzes.

\section{References}

Agassounon, D. T. M., Bada, F., Ahanhanzo, C., Adisso, S. A., Toukourou, F., De souza, C., 2011. Effets des huiles essentielles sur les qualités hygiéniques et organoleptiques de la boisson "bissap". Rev. Indust. Microbiol. Sanit. Environ. 5(1), 1-23.

Andrieu, E., Caillavet, F., Huissier, A., Momic, M., Régnier, F., 2006. L'alimentation comme dimension spécifique de la pauvreté. Approches croisées de la consommation alimentaire des ménages défavorisés. Les Travaux de l'Observatoire, Deuxième partie, Cahier. 1, 247- 278.
Brause, A. R., Mary, W. T., Frederick, S. T., Samuel, W., 1996. Determination of patulin in apple juice by liquid chromatography: Collaborative study. J. AOAC Inter. 79(2), 451455.

Ehouman, A., Yao, B., Hampoh, A., Fofana, A., Traore, K., Tano, K., 2017. Mycotoxins in food: Evaluation of aflatoxin B1 and ochratoxin A in a few foodstuffs in Côte d'Ivoire Int. J. Curr. Res. Biosci. Plant Biol. 4(11), 1-8.

INRA., 2007. Les fruits et légumes dans l'alimentation: enjeux et déterminants de la consommation. Synthèse du rapport d'expertise réalisé par l'INRA à la demande du Ministère de l'Agriculture et de la Pêche. $88 \mathrm{P}$. disponible sur «www.inra.fr », visité le 9 Février 2019.

Kouassi, C., Coulibaly, I., Coulibaly, B., Konate, I., 2018. Diagnosis and characteristics of street food consumption in a city with high population growth: case of Daloa (Côte d'Ivoire). Inter. J. Sci. Res. 7(6), 1129-1133.

KpanKpan, K. G., Kouacou, K. W. D., Kouakou, K. J-M., Yao, B. L., Trokourey, A., Dembele, A., 2019. Validation of HPLC-UV patulin determination method in traditional juices from Côte d'Ivoire. Eur. Sci. J. 15(36), 253-266.

Mihajlovic, B., Dixon, B., Couture, H., Farber, J., 2013. Évaluation qualitative des risques microbiologiques que comportent les jus non pasteurisés de pomme et d'autres fruits. Int. Food Risk Anal. J. 3(6), 1-22.

Ndiaye, N., Dieng, M., Kane, A., Cisse, M., Montet, D., Toure, N.C., 2015. Diagnostic et caractérisation microbiologique des procédés artisanaux de fabrication de boissons et de concentrés d'Hibiscus sabdariffa L. au Sénégal. Afr. Sci. 11(3), 197-210.

Tannous, J., 2015. Patuline, mycotoxine de Penicillium expansum, principale photogenèse post-récolte des pommes : nouvelles données sur la biosynthèse et le développement d'approches préventives. Thèse de doctorat, Université de Toulouse, France, 208P.

\section{How to cite this article:}

Ehouman, A. G. S., Kouassi, K. A., Kouakou, K. J-M., Beugre, G. A. M., Traore, K. S., 2020. Contamination of some non-alcoholic drinks by patulin sold in the streets of Daloa (Côte d'Ivoire): case of Bissap (Hibiscus sabdariffa), Gnamankoudji (Zingiber officinale rhizomes) and Tomi (Tamarindus indica). Int. J. Curr. Res. Biosci. Plant Biol. 7(5), 1-6. doi: https://doi.org/10.20546/ijcrbp.2020.705.001 